\title{
PENGARUH MODAL PSIKOLOGIS DAN PERSEPSI GAYA KEPEMIMPINAN TRANSFORMASIONAL TERHADAP WORK- PLACE WELL BEING
}

\author{
Anita Yuniarti \\ Anita.wasito@yahoo.com \\ Desi Yustari Muchtar \\ Fakultas Psikologi \\ UIN Syarif Hidayatullah Jakarta
}

\begin{abstract}
This study aims to determine the effect of psychological capital and the perception of transformational leadership style to the workplace well being of employees. This study uses quantitative approach with multiple regression analysis involving a sample of 220 civil servants of the Ministry X. The sampling technique used in this study is a non-probability sampling. To measure workplace wellbeing, researchers compiled independently of workplace wellbeing scale based on the theory of workplace well being developed by Page (2005). Then, the instrument used to measure the psychological capital is Psychological Capital Quessionare 24 (PCQ-24) developed by Luthans, Youssef \& Avolio (2007). Furthermore, measuring instruments used to measure the perception of transformational leadership is a modification of the measuring instrument multifactor Leadership questionnare factor (MLQ). Based on the results of hypothesis testing, first conclusions obtained from this study is a significant difference of perception psychological capital dan transformational leadership style on workplace well being on the employees of the Ministry X. Then based on the results of tests of significance of each regression coefficient on the dependent variable, there are four variables were obtained significant regression coefficient values, namely; (1) hope dimension of psychological capital; (2) the dimension idealized influence of transformational leadership style; (3) the dimensions of intellectual stimulation transformational leadership style; and (4) individualized consideration dimensions of transformational leadership style.
\end{abstract}

Keyword: $\quad$ workplace well being, psychological capital, perception of transformational leadership style 


\section{PENDAHULUAN}

Kesejahteraan karyawan merupakan salah satu faktor yang tidak bisa lepas dari isu penting dalam suatu perusahaan, karena kesejahteraan karyawan memiliki implikasi langsung terhadap fisik, psikologis dan perilaku karyawan. Selain itu, kesejahteraan juga memiliki hubungan dengan biaya yang berhubungan dengan penyakit dan kesehatan karyawan, ketidakhadiran (absenteeism) dan produktiftas (Danna \& Griffin, 1999). Dengan kata lain, dapat diambil kesimpulan bahwa kesejahteraan karyawan dapat membawa pengaruh yang positif terhadap performa seseorang, baik di tempat kerjanya maupun dalam kehidupan sehari-hari.

Karyawan merupakan aset penting bagi perusahaan. Oleh karena itu, perhatian seharusnya tidak hanya diarahkan pada sarana dan proses produksinya saja, tetapi juga harus ditujukan kepada pribadi karyawan dengan kesejahteraannya. Karyawan seharusnya tidak lagi dianggap sebagai robot, karena aktivitas karyawan dan kegiatan sosial dapat mempengaruhi fungsi dari kegiatan produksi industri tersebut. Dalam hal ini manajemen personalia sangat penting sekali dalam pengelolaan karyawan dengan sebaik mungkin melalui kebijakan yang dapat meningkatkan kesejahteraan psikologis karyawannya.

Salah satu jenis kesejahteraan karyawan yang penting untuk diperhatikan adalah workplace wellbeing. Penulis memiliki asumsi bahwa workplace well-being (kesejahteraan pekerja di tempat kerja) adalah wellbeing yang dekat hubungannya dengan pekerja dan lingkungan kerja, karena karyawan menghabiskan sebagian besar waktunya di lingkungan kerja. Oleh karena itu, penelitian ini akan difokuskan pada workplace well being tersebut.

Menurut Page (2005) workplace well-being (selanjutnya akan disingkat WWB) merupakan salah satu cabang dari subjective well-being yang diterapkan dalam setting kerja. Jika subjective well-being merupakan kepuasan secara umum terhadap seluruh aspek kehidupan, maka kepuasan tersebut dapat juga difokuskan pada salah satu aspek, seperti pekerjaan. Penjelasan lebih lanjut mengenai definisi workplace well-being akan dipaparkan pada bab 2.

Para peneliti di bidang kesehatan dan psikologi kesehatan telah menunjukkan bahwa kesejahteraan dipengaruhi oleh beberapa hal, diantaranya adalah: self-efficacy, optimisme, harapan, dan ketahanan (Avey, Luthans \& Jensen, 2010). Selanjutnya, variabel-variabel tersebut oleh Avey et al. (2010) dieksplorasi sebagai komponen dari suatu konstruk psikologi yang disebut dengan modal psikologis 
Modal psikologis sendiri dapat diartikan sebagai modal sikap dan perilaku yang berperan besar dalam menentukan keberhasilan. Penelitian menunjukkan bahwa keempat komponen dari modal psikologis (selfefficacy, optimisme, harapan, dan ketahanan) memiliki hubungan positif dengan kinerja, kebahagiaan, well being, dan kepuasan pekerja. Misalnya, self-efficacy telah ditemukan memiliki dampak positif pada kinerja (Stajkovic \& Luthans, 1998). Optimisme karyawan berhubungan dengan kinerja karyawan, kepuasan, dan kebahagiaan (Youssef \& Luthans, 2007). Harapan terkait dengan kinerja karyawan, kepuasan, kebahagiaan, dan retensi (Youssef \& Luthans, 2007). Ketahanan memiliki hubungan positif dengan kinerja karyawan, kebahagiaan dan kepuasan (Youssef \& Luthans, 2007). Dengan kata lain, dapat disimpulkan bahwa keempat komponen dari modal psikologis merupakan faktor penting yang dapat mempengaruhi perilaku positif dalam organisasi dan dunia kerja, termasuk workplace well being.

Selain keempat komponen dari modal psikologis, faktor lain yang juga perlu diperhatikan ketika membicarakan kesejahteraan adalah gaya kepemimpinan transformasional. Para peneliti telah menemukan bukti bahwa kepemimpinan transformasional membawa pengaruh yang positif terhadap perilaku dan emosi karyawan (Bono \& Ilies, 2006). Menurut Ghadi, Fernando, dan Caputi (2010), kepemimpinan transformasional adalah salah satu paradigma yang paling dominan dalam kepemimpinan kontemporer karena memiliki pengaruh yang cukup besar terhadap hasil yang diinginkan dalam dunia kerja, seperti kesejahteraan, komitmen organisasi dan kepuasan kerja.

Kepemimpinan transformasional pada prinsipnya memotivasi bawahan untuk berbuat lebih baik dari apa yang biasa dilakukan. Dalam hal ini kepemimpinan transformasional mengacu pada aspek kepercayaan atau keyakinan diri pada karyawan, sehingga karyawan akan merasa dipercaya, dihargai, loyal dan respek kepada pimpinannya. Hal ini akan berpengaruh terhadap peningkatan kesejahteraan karyawan.

Kepemimpinan transformasional juga dapat mengurangi stres yang dialami oleh individu melalui dampaknya pada fungsi mentoring. Selain itu, penelitian juga menemukan bahwa kepemimpinan transformasional memiliki pengaruh terhadap kepuasan kerja (Bushra, Usman \& Naveed, 2011). Riaz dan Haider (2010) menyebutkan bahwa gaya kepemimpinan transformasional memiliki pengaruh yang lebih baik terhadap kinerja, inovasi dan kepuasan kerja jika dibandingkan dengan gaya kepemimpinan transaksional.

Kepemimpinan transformasional memiliki efek positif pada 
kesejahteraan pemimpin dan pengikut. Salah satu aspek dari kesejahteraan yang baru-baru ini mendapat perhatian sehubungan dengan efek kepemimpinan transformasional adalah keselamatan kerja. Penelitian terbaru menunjukkan bahwa kepemimpinan transformasional meningkatkan kinerja keselamatan karyawan (Sivanathan, Arnold, Turner \& Barling, 2004).

\section{Teori dan Hipotesis}

\section{Workplace Well being}

Page (2005) mengemukakan bahwa workplace well-being didasari oleh nilai instrinsik dan ekstrinsik dari pekerjaan. Nilai tersebut berasal dari teori dualitas motivasi yang seringkali menjadi telaah para ahli psikologi organisasi. Motivasi instrinsik merujuk pada dorongan untuk bekerja yang disebabkan oleh penghargaan bersifat psikologis yang diasosiasikan dengan pekerjaan itu sendiri, seperti prestasi dan tanggung jawab. Sedangkan motivasi ekstrinsik lebih disebabkan oleh keinginan untuk mendapatkan hal yang berhubungan dengan faktor eksternal dari pekerjaan, seperti upah (Page, 2005).

Dalam penelitian ini, penulis akan menggunakan workplace wellbeing dari Page (2005) yaitu perasaan sejahtera yang karyawan peroleh dari pekerjaan, yang terkait dengan perasaan pekerja secara umum (core affect) dan terdiri dari nilai intrinsik maupun ekstrinsik dari pekerjaan.

Dimensi intrinsik: tanggung jawab dalam kerja, makna pekerjaan, emandirian dalam pekerjaan, penggunaan kemampuan dan pengetahuan dalam kerja dan dimensi ekstrinsik: penggunaan waktu yang sebaik mungkin, kondisi kerja, supervisi, peluang promosi, pengakuan terhadap kinerja yang baik, penghargaan sebagai individu di tempat kerja, upah, keamanan pekerjaan.

\section{Modal psikologis}

Meskipun istilah modal psikologis telah dibanyak disebutkan dalam berbagai penelitian ekonomi dan sosiologi, para ahli psikologi memiliki definisi yang berbeda. Secara khusus, para ahli psikologi berfokus pada kekuatan yang ada dalam diri individu, bukan kelemahan, kesehatan dan vitalitas daripada penyakit dan patologi. Istilah modal psikologis pertama kali muncul dalam buku yang berjudul Authentic Happiness karangan Martin Selligman (Luthans, Luthans \& Luthans, 2004).

Dalam Positive Organizational Behavior, Luthans et al. (2007) mengidentifikasi konstruk positif dari self-efficacy, harapan, optimisme 
dan ketahanan modal psikologis yang berperan besar dalam menentukan keberhasilan individu di dunia kerjanya. Alasan menggabungkan empat komponen ini adalah karena keempat komponen inilah yang mendasari sumber daya psikologis yang memungkinan individu memiliki tingkat kapasitas yang lebih tinggi untuk tampil konsisten daripada hanya satu komponen saja.

Kemudian Luthans et al. (2007:3), mendefinisikan modal psikologis Yaitu: "An individual's positive psychological state of development that is characterized by: (1) having confidence (Self-efficacy) to take on and put in the necessary effort to succeed at challenging tasks; (2) making a positive attribution (optimism) about succeeding now and in the future; (3) persevering toward goals, and when necessary redirecting paths to goals (Harapan) in order to succeed; and (4) when beset by problems and adversity, sustaining and bouncing back and even beyond (resilience) to attain success."

Dari definisi ini, kita dapat melihat bahwa modal psikologis terdiri dari 4 dimensi (Self-efficacy, optimisme, harapan dan ketahanan) yang satu dengan yang lain memiliki benang merah dari kecenderungan motivasi untuk mencapai tujuan dan sukses. Secara keseluruhan, modal psikologis telah dibuktikan secara konseptual dan secara empiris dapat memprediksi hasil kerja yang diinginkan seperti kinerja dan kepuasan kerja (Avey, Luthans, Smith \& Palmer, 2010).

Selain itu, menurut Avey, Luthans \& Jensen (2009) definisi ini juga membedakan konstruk modal psikologis dari aspek yang telah ada sebelumnya seperti human capital (seperti pengetahuan, keterampilan, kemampuan, dan pengalaman) dan social capital (seperti mengenal diri sendiri, hubungan orang lain, dan lain-lain). Konsep modal psikologis menggabungkan human capital dan social capital untuk memperoleh keutungan kompetitif melalui pengembangan identitas diri seseorang (Luthans \& Avolio, 2003).

Dalam penelitian ini, penulis menggunakan definisi modal psikologis dari Luthans et al. (2007), yaitu hal positif psikologis yang dimiliki oleh setiap individu yang berguna untuk dapat membantu individu tersebut untuk dapat berkembang dan sukses.

Dimensi Modal Psikologis : Self-efficacy, Istilah Self-efficacy muncul pertama kali dalam teori belajar sosial Albert Bandura (Bandura, 1977). Menurut teori ini, Self-efficacy membuat perbedaan pada bagaimana orang merasa, berpikir, berperilaku, dan memotivasi diri. Bandura (1977) menjelaskan pentingnya Self-efficacy sebagai keyakinan yang berfungsi sebagai serangkaian tindakan penting yang dapat mempengaruhi motivasi, 
afektif, dan tindakan individu (Zulkosky, 2009). Sementara itu Luthan et al. (2004) mendefinisikan Self-efficacy sebagai keyakinan individu tentang kemampuannya untuk memobilisasi motivasi, sumber daya kognitif, dan tindakan yang diperlukan untuk berhasil melaksanakan suatu tugas dalam konteks tertentu. Optimisme, Luthans et al. (2007) mendefinisikan optimisme sebagai model pemikiran yang memungkinkan individu mengatribusikan kejadian positif ke dalam diri sendiri, bersifat permanen, di lain hal menginterpretasikan kejadian negatif kepada aspek eksternal, bersifat sementara atau temporer, dan merupakan faktor yang disebabkan oleh situasi tertentu. Pengertian optimis menggambarkan keyakinan bahwa sesuatu yang baik akan diperoleh.

Dalam dunia kerja, optimisme ini juga berhubungan secara positif kepada hal yang memuaskan seperti workplace performance dan performa di berbagai aspek kehidupan seperti pendidikan, olahraga dan politik. Sedangkan, untuk hal negatif yang dapat dihasilkannya adalah seperti depresi, penyakit fisik dan rendahnya performa disetiap bidang kehidupan. Optimisme sebagai segi modal psikologis dikaitkan dengan pandangan positif realistis tetapi bukan proses yang tanpa evaluasi (Luthans et al., 2007). Harapan, Snyder et al. (2002) mendefinisikan harapan sebagai kodisi motivasi positif yang didasari oleh interaksi akan perasaan sukses (1) agency (goal-directed energy) dan (2) pathways (planning to meet goals). Dengan kata lain, harapan terdiri dari dua point penting, yaitu; agency/wiilpower yang merupakan determinasi untuk mencapai tujuan; dan waypower yang merupakan rencana alternatif hasil pemikiran seseorang untuk mencapai tujuannya.

Dalam berbagai penelitian, harapan ditemukan berpengaruh positif terhadap kinerja yang lebih baik (Luthans et al., 2007). Ketahanan, Ketahanan didefinisikan sebagai kapasitas psikologis seseorang yang bersifat positif, dengan menghindarkan diri dari ketidakbaikan, ketidakpastian, konflik, kegagalan, sehingga dapat menciptakan perubahan positif, kemajuan dan peningkatan tanggung jawab (Luthans et al., 2007). Berbeda dengan selfefficacy, optimisme, dan harapan yang lebih bersifat proaktif, ketahanan dari seseorang lebih bersifat reaktif, yang terjadi ketika seseorang berhadapan dengan perubahan, ketidakbaikan, atau ketidakpastian (Luthans et al., 2007). Alat ukur yang dapat mengukur modal psikologis adalah Psychological Capital Quessionare 24 (PCQ-24) yang dikembangkan oleh Luthans et al. (2007). Dalam PCQ-24 ini setiap dimensi terdiri dari 6 skala yang diadopsi dari alat ukur yang telah ada sebelumnya tentang dimensi dalam modal psikologis. Skala self-efficacy diadaptasi dari skala milik Parker yang mengukur self-efficacy dalam situasi kerja. Skala optimisme diadaptasi dari 
skala milik Scheier dan Carver. Skala harapan diadaptasi dari skala harapan milik Snyder dan kawan-kawan. Sementara skala ketahanan diadaptasi dari skala Wagnild dan Young (Avey et al., 2010). Semua item diukur dengan menggunakan skala Likert 6-point dengan pilihan respon mulai dari $1=$ sangat tidak setuju sampai $6=$ sangat setuju. PCQ-24 ini memiliki koefisien realibilitas 0,92 (Avey et al., 2009). Dalam penelitian ini, penulis akan menggunakan modifikasi skala PCQ-24 ini. Alasan memodifikasi skala ini adalah untuk menyesuaikan dengan kebutuhan penelitian.

\section{Kepemimpinan Transformasional}

Beberapa teori tentang kepemimpinan transformasional didasarkan pada ide dari Burns (1978), inti dari teori ini ialah para pengikut merasakan kepercayaan, kekaguman, kesetiaan, dan penghormatan terhadap pemimpin, termotivasi untuk melakukan lebih daripada yang awalnya diharapkan dari. Sivanathan et al. (2004) mengemukakan kepemimpinan transformasional merupakan gaya kepemimpinan di mana para pemimpin tidak dibatasi oleh persepsi pengikut tetapi bebas dalam bertindak untuk mengubah serta mempengaruhi pengikutnya.

Bass (1990) mengemukakan kepemimpinan transformasional terjadi jika pemimpin mampu memperluas dan meningkatkan kepentingan karyawannya sehingga mendapatkan hasil dari apa yang menjadi tujuan pada suatu kelompok tersebut. Selanjutnya, Yukl (1999) menyatakan bahwa kepemimpinan transformasional dan transaksional itu berbeda, kepemimpinan transformasional lebih meningkatkan motivasi kerja dan kinerja pengikutnya sedangkan kepemimpinan transaksional mengukur pada tingkat pengaruh pemimpin terhadap bawahannya serta pencapaian tingkat kinerja yang telah disepakai oleh pemimpin dan bawahannya yang berkaitan pada imbalan yang akan diterima oleh bawahannya. Kepemimpinan transaksional melibatkan sebuah proses pertukaran yang dapat menghasilkan kepatuhan pengikut akan permintaan pemimpin tetapi tidak menghasilkan antusiasme dan komitmen terhadap sasaran tugas.

Persepsi kepemimpinan transformasional dalam penelitian ini menggunakan definisi dari Bass (1990) yang mengemukakan bahwa kepemimpinan transformasional adalah persepsi yang diterima bawahan terhadap gaya kepemimpinan pemimpin yang memiliki kemampuan untuk mempengaruhi, memotivasi dan mengilhami bawahan agar berbuat lebih dari yang diharapkan, serta terbuka terhadap bawahan dan pada setiap perubahan atau permasalahan yang terjadi di perusahaan.

Dimensi Kepemimpinan Transformasional menurut Bass (dalam Sivanathan et al., 2004) mengemukakan bahwa kepemimpinan 
transformasional memiliki empat aspek yaitu : Idealized influence. Pemimpin berusaha, melalui pembicaraan, mempengaruhi bawahan dengan menekankan pentingnya nilai dan keyakinan, pentingnya keikatan pada keyakinan (beliefs), perlu dimilikinya tekad mencapai tujuan, perlu diperhatikan akibat moral dan etik dari keputusan yang diambil. Pemimpin memperlihatkan kepercayaannya pada cita - citanya, keyakinannya dan nilai hidupnya. Inspirational Leadership, Pemimpin mampu menimbulkan inspirasi pada bawahannya, antara lain dengan menentukan standar tinggi, memberikan keyakinan bahwa tujuan dapat dicapai.

Bawahan merasa mampu melakukan tugas pekerjaannya, mampu memberikan berbagai macam gagasan dan merasa diberi inspirasi oleh pimpinannya. Intellectual stimulation, Bawahan merasa bahwa pimpinan mendorong untuk memikirkan kembali cara kerja yang ada, untuk kemudian mencari cara baru dalam melaksanakan tugas dan merasa mendapatkan cara baru dalam mempersepsi tugas. Individualized consideration, bawahan merasa diperhatikan dan diperlakukan secara khusus oleh pimpinannya. Pemimpin memperlakukan setiap bawahannya sebagai seorang pribadi dengan kecakapan, kebutuhan, keinginannya masing - masing.

Pengukuran Kepemimpinan Transformasional. Untuk mengetahui kepemimpinan transformasional pada individu dapat digunakan alat ukur yang mengadaptasi dari Bass dan Avolio dalam Beşiktaş dan Orta (2012) yaitu Multifactor Leadership Quetionnaire (MLQ). Alat ukur ini berisi pernyataan dengan pilihan ganda dan pilihan isian. Pernyataan dengan pilihan ganda digunakan untuk memperoleh informasi mengenai perilaku kepemimpinan transformasional dengan empat aspeknya. Sedangkan pernyataan dengan isian digunakan untuk memperoleh informasi berkaitan dengan data kontrol seperti jenis kelamin, usia, masa kerja, agama, nama, departemen dan posisi jabatan.

Dalam penelitian ini, penulis akan menggunakan skala Multifactor Leadership Quetionnaire (MLQ) dari Bass dan Avolio (1990) dalam Beşiktaş dan Orta (2012). Pemilihan alat ukur ini karena sesuai dengan teori yang digunakan dalam penelitian ini.

\section{Hipotesis}

Peneliti berasumsi bahwa:

$\mathrm{H}_{1}$ : Terdapat pengaruh yang signifikan modal psikologis dan persepsi gaya kepemimpinan transformasional terhadap workplace well being 
Hipotesis minor:

$\mathrm{H}_{2}$ : Terdapat pengaruh yang signifikan self-efficacy terhadap workplace well being

$\mathrm{H}_{3:}$ Terdapat pengaruh yang signifikan optimisme terhadap workplace well being

$\mathrm{H}_{4:}$ Terdapat pengaruh yang signifikan harapan terhadap workplace well being

$\mathrm{H}_{5}$ : Terdapat pengaruh yang signifikan ketahanan terhadap workplace well being

$\mathrm{H}_{6}$ : Terdapat pengaruh yang signifikan

idealized influence terhadap workplace

well being

$\mathrm{H}_{7:}$ Terdapat pengaruh yang signifikan inspirational Leadership terhadap workplace well being

$\mathrm{H}_{8:}$ Terdapat pengaruh yang signifikan

intellectual stimulation terhadap

workplace well being

$\mathrm{H}_{9}$ : Terdapat pengaruh yang signifikan individualized consideration terhadap workplace well being

\section{Sampel dan Prosedur}

Populasi dalam penelitian ini adalah para Pegawai Negeri Sipil Kementerian $\mathrm{X} 1.200$ orang. Adapun jumlah sampel yang digunakan dalam penelitian ini adalah sebanyak 220 orang. Adapun pengambilan sampel dalam penelitian ini termasuk kategori non-probability sampling

\section{Instrumen Data}

Untuk mengukur workplace wellbeing, penulis menyusun secara mandiri skala workplace wellbeing berdasarkan pada teori workplace well being yang dikembangkan oleh Page (2005). Dalam teori Page (2005), workplace well being terdiri dari 2 dimensi, yaitu dimensi intrinsik dan dimensi ekstrinsik. Dimensi intrinsik sendiri terdiri dari 5 aspek, yaitu; (a) tanggung jawab dalam kerja, (b) Makna pekerjaan, (c) kemandirian dalam pekerjaan, (d) penggunaan kemampuan dan pengetahuan dalam kerja, dan (e) perasaan berprestasi dalam bekerja. Sedangkan dimensi ekstrinsik terdiri dari delapan aspek, yaitu: (a) penggunaan waktu yang sebaik-sebaiknya, (b) kondisi kerja, (c) supervisi, (d) peluang promosi, (e) pengakuan terhadap kinerja yang baik, (f) penghargaan sebagai individu di tempat kerja, (g) upah, (h) keamanan pekerjaan. Skala ini berbentuk skala likert dengan rentangan 1-4 dari sangat setuju sampai sangat tidak setuju. 
Instrumen atau alat ukur modal psikologis yang digunakan dalam penelitian ini adalah adaptasi dari Psychological Capital Quessionare 24 (PCQ-24) yang dikembangkan oleh Luthans, Youssef dan Avolio, (2007). Dalam PCQ-24 ini masing-masing dimensi terdiri dari 6 skala yang diadopsi dari alat ukur yang telah ada sebelumnya tentang dimensi dalam modal psikologis. Skala self-efficacy diadaptasi dari skala milik Parker yang mengukur self efficacy dalam situasi kerja. Skala optimisme diadaptasi dari skala milik Scheier dan Carver (Avey, Luthans, Smith, \& Palmer, 2010). Skala Hope (harapan) diadaptasi dari skala hope milik Snyder dan kawan-kawan. Sementara, skala resiliensi atau ketahanan diadaptasi dari skala Wagnild dan Young. Dalam skala aslinya, semua item diukur dengan menggunakan skala Likert 6-point dengan pilihan respon mulai dari $1=$ sangat tidak setuju sampai $6=$ sangat setuju. Akan tetapi, untuk menyesuaikan dengan kebutuhan penelitian, skala ini dimodifikasi menjadi setiap dimensi terdiri dari empat item dan juga empat pilihan jawaban, yaitu sangat setuju, setuju, tidak setuju, sangat tidak setuju.

Instrumen atau alat ukur yang digunakan untuk mengukur persepsi kepemimpinan transformasional adalah modifikasi dari alat ukur Multifactor Leadership Questionnare factor (MLQ). MLQ ini digunakan untuk mengukur kepemimpinan melalui 7 aspek gaya kepemimpinan, yaitu: Idealized Influence, Inspirational leadership, Intellectual Stimulation, Individualized Consideration, Contingent Reward, Management-byexception dan Laissez-faire Leadership. Namun, pada penelitian ini peneliti hanya menggunakan 12 item yang mengukur 4 aspek dari kepemimpian transformasional. Instrumen ini berbentuk skala Likert dengan rentang 4 point, yaitu dari "1" (sangat tidak setuju), "2" (tidak setuju), "3" (setuju) dan "4" (sangat setuju).

\section{Hasil Penelitian}

\section{Uji Validitas Konstruk}

Workplace well being. Penulis menggunakan model multifactorial untuk menguji alat ukur workplace wellbeing beserta kedua dimensinya. Penulis menguji apakah item-item yang ada bersifat unidimensional, artinya benar semua item mengukur sesuai dengan yang seharusnya diukur. Berdasarkan analisis CFA yang dilakukan, hasilnya ternyata tidak fit dengan nilai Chi-Square $=4457.85, \quad \mathrm{df}=1273, \quad \mathrm{P}$-value $=0.00000, \quad \mathrm{RMSEA}=0.106$. Oleh karena itu, penulis melakukan modifikasi terhadap model, dimana kesalahan pengukuran pada item dibebaskan berkorelasi satu sama lain. Setelah dilakukan 263 kali modifikasi, diperoleh model fit dengan Chi- 
Square $=1061.99, \mathrm{df}=1010, \mathrm{P}$-value $=0.12460, \mathrm{RMSEA}=0.015$.

Modal psikologis. Penulis menguji apakah item-item yang ada bersifat unidimensional, artinya benar semua item mengukur sesuai dengan yang seharusnya diukur. Berdasarkan analisis CFA yang dilakukan, hasilnya ternyata tidak fit dengan nilai Chi-Square $=545.88, \mathrm{df}=98$, P-value $=0.00000$, RMSEA $=0.144$. Oleh karena itu, penulis melakukan 33 kali modifikasi terhadap model, dimana kesalahan pengukuran pada item dibebaskan berkorelasi satu sama lain, maka diperoleh model fit dengan Chi-Square $=79.16, \mathrm{df}=65, \mathrm{P}$-value $=0.11144$, $\mathrm{RMSEA}=0.031$.

Persepsi gaya kepemimpinan transformasional. Penulis menguji apakah item-item yang ada bersifat unidimensional, artinya benar semua item mengukur sesuai dengan yang seharusnya diukur. Berdasarkan analisis CFA yang dilakukan, hasilnya ternyata tidak fit dengan nilai ChiSquare $=191.81, \mathrm{df}=48, \mathrm{P}$-value $=0.00000, \mathrm{RMSEA}=0.116$. Oleh karena itu, penulis melakukan 13 kali modifikasi terhadap model, dimana kesalahan pengukuran pada item dibebaskan berkorelasi satu sama lain, maka diperoleh model fit dengan Chi-Square $=45.57, \mathrm{df}=36, \mathrm{P}$-value $=0.13178$, RMSEA $=0.035$.

\section{Uji Hipotesis}

Pada tabel 1 dapat dilihat bahwa diperoleh R-Square sebesar 0.279 atau $27,9 \%$. Artinya, proporsi varian dari workplace wellbeing yang dijelaskan oleh persepsi kepemimpinan transformasional dan psychological capital adalah sebesar $27,9 \%$, sedangkan $72,1 \%$ sisanya dipengaruhi oleh variabel lain di luar penelitian ini. Langkah kedua peneliti menguji apakah seluruh independen memiliki pengaruh yang signifikan terhadap workplace wellbeing

Tabel 4.5

Varians workplace wellbeing yang dijelaskan oleh seluruh IV

\begin{tabular}{ccccc}
\hline Model & $\mathrm{R}$ & R Square & Adjusted R Square & $\begin{array}{c}\text { Std. Error of the } \\
\text { Estimate }\end{array}$ \\
\hline 1 & $.528^{\mathrm{a}}$ & .279 & .251 & 9.09278 \\
\hline
\end{tabular}

a. Predictors: (Constant), Individualized_Consideration, Optimisme, resiliensi, harapan,Intellectual_Stimulation, Self_efficacy, Idealized_ Influence, Inspirational_Learning

Berdasarkan uji F pada tabel 2, dapat dilihat bahwa nilai p (Sig.) pada kolom paling kanan adalah $\mathrm{p}=0.000$ dengan nilai $\mathrm{p}<0.05$. Jadi Hipotesis nihil yang berbunyi "tidak ada pengaruh modal psikologis dan persepsi kepemimpinan transformasional terhadap workplace wellbeing" ditolak 
Tabel 4.6

Anova pengaruh seluruh IV terhadap workplace wellbeing

\begin{tabular}{|c|c|c|c|c|c|}
\hline Model & Sum of Squares & $\mathrm{df}$ & $\begin{array}{l}\text { Mean } \\
\text { Square }\end{array}$ & $\mathrm{F}$ & Sig. \\
\hline Regression & 6744.884 & 8 & 843.110 & 10.197 & $.000^{\mathrm{a}}$ \\
\hline 1 Residual & 17445.185 & 211 & 82.679 & & \\
\hline Total & 24190.069 & 219 & & & \\
\hline
\end{tabular}

a. Predictors: (Constant), Individualized_Consideration, Optimisme, resiliensi, harapan, Intellectual_Stimulation, Self_efficacy, Idealized Influence, Inspirational Learning b. Dependent Variable: WWB

Selanjutnya dilihat signifikan atau tidaknya koefisien regresi dari masing-masing IV. Adapun penyajiannya ditampilkan dalam tabel 3 berikut ini.

Tabel 4.7

Koefisien Regresi

\begin{tabular}{|c|c|c|c|c|c|}
\hline \multirow[b]{3}{*}{ Model } & \multicolumn{3}{|c|}{ Coefficients $^{\mathrm{a}}$} & \multirow[b]{3}{*}{$\mathrm{T}$} & \multirow[b]{3}{*}{ Sig. } \\
\hline & $\begin{array}{r}\text { Unsta } \\
\text { Coe }\end{array}$ & $\begin{array}{l}\text { ardized } \\
\text { cients }\end{array}$ & $\begin{array}{l}\text { Standardized } \\
\text { Coefficients }\end{array}$ & & \\
\hline & $\mathrm{B}$ & Std. Error & Beta & & \\
\hline 1 (Constant) & 4.417 & 7.728 & & .572 & .568 \\
\hline Self efficacy & .022 & .054 & .026 & .415 & .678 \\
\hline Optimisme & -.036 & .063 & -.034 & -.571 & .569 \\
\hline Harapan & .197 & .066 & .183 & 2.994 & .003 \\
\hline Resiliensi & .063 & .069 & .058 & .910 & .364 \\
\hline Idealized Influence & 346 & .061 & .346 & 5.712 & .000 \\
\hline $\begin{array}{l}\text { Inspirational_ } \\
\text { Learning }\end{array}$ & -.044 & .052 & -.050 & -.842 & .401 \\
\hline Intellectual_ & .175 & .053 & .193 & 3.295 & .001 \\
\hline $\begin{array}{l}\text { Stimulation } \\
\text { Individualized } \\
\text { Consideration }\end{array}$ & 202 & .063 & .192 & 3.186 & .002 \\
\hline
\end{tabular}

a. Dependent Variable: WWB

Dari persamaan regresi tersebut, dapat diketahui bahwa terdapat empat varibel yang nilai koefisien regresinya signifikan, yaitu; (1) harapan; (2) idealized influence; (3) intellectual stimulation; dan (4) individualized consideration. 


\section{Diskusi}

Fokus pada penelitian ini adalah untuk mengetahui faktor-faktor yang dapat mempengaruhi kesejahteraan (wellbeing) karyawan. Menurut Page (2005) workplace well-being merupakan salah satu cabang dari subjective well-being yang diterapkan dalam setting kerja. Jika subjective well-being merupakan kepuasan secara umum terhadap seluruh aspek kehidupan, maka kepuasan tersebut dapat juga difokuskan pada salah satu aspek, seperti pekerjaan.

Yang menjadi variabel bebas adalah modal psikologis dan persepsi kepemimpinan trasformasional. Penelitian sebelumnya terkait modal psikologis dan wellbeing karyawan memang masih hanya terbatas pada subjective wellbeing dan psychological wellbeing. Peneliti belum menemukan penelitian mengaitkan secara langsung modal psikologis dengan workplace wellbeing. Sehingga, bisa dikatakan temuan dalam penelitian ini merupakan temuan yang baru. Peneliti pun menduga hal ini lah yang menyebabkan ditemukannya beberapa dimensi dari modal psikologis yang tidak memberikan pengaruh signifikan terhadap workplace wellbeing.

Dalam penelitian ini, ditemukan hanya satu dimensi dari modal psikologis yang memberikan pengaruh signifikan terhadap workplace wellbeing, yaitu harapan. Temuan dalam penelitian ini menguatkan penelitian pada bidang kesehatan kerja dan kesehatan psikologis sebelumnya yang menemukan bahwa harapan memiliki keterkaitan dengan wellbeing. Contohnya, penelitian yang dilakukan Snyder et al. (2002) menjelaskan bahwa harapan merupakan sumber daya yang harus dimiliki seseorang untuk dapat mencapai kesejahteraan di tempat kerja dan dalam berbagai aspek kehidupan. Penelitian lain yang menyebutkan bahwa harapan dapat memberikan pengaruh terhadap well being karyawan adalah penelitian yang dilakukan oleh Park, Peterson, dan Seligman (2004).

Snyder et al. (2002) mendefinisikan harapan sebagai sebagai kodisi motivasi positif yang didasari oleh interaksi akan perasaan sukses (1) agency (goal-directed energy) dan (2) pathways (planning to meet goals). Harapan merupakan sumber motivasi yang memiliki komponen kognitif. Sumber daya psikologis ini memberikan harapan bahwa sasaran akan dicapai. Orang dengan harapan yang tinggi sangat termotivasi untuk mencapai keberhasilan dalam tugas. Mempertahankan harapan selama masa krisis merupakan aspek penting yang harus dimiliki untuk mencapai kesejahteraan pada karyawan. Selain itu, Park et al. (2004) juga menyoroti bahwa individu dengan harapan tinggi cenderung memiliki pandangan yang positif tentang masa depan. Pada gilirannya, keyakinan ini memungkinkan 
seseorang untuk memiliki pandangan yang positif tentang diri sendiri yang akan membantu dalam peningkatan motivasi dan menyebabkan berujung kegiatan dan sarana yang diarahkan aktif mengejar tujuan pribadi, sehingga individu dengan harapan yang tinggi cenderung akan lebih mampu mencapai kesejahteraannya.

Akan tetapi, meski terdapat hasil penelitian yang menunjukkan bahwa harapan memberikan pengaruh positif terhadap well being, ditemukan pula hasil penelitian lain yang menunjukkan bahwa harapan tidak memberikan pengaruh positif terhadap well being. Penelitian yang dilakukan oleh Malik (2013) menemukan bahwa dimensi ini tidak memberikan pengaruh yang signifikan terhadap kesejahteraan karyawan. Dalam penelitiannya tersebut, hanya self efficacy dan ketahanan yang memberikan efek terhadap kesejahteraan karyawan. Selain itu, menurut Nash dan Stewart (2005), harapan mampu memberikan efek terhadap kesejahteraan bagi para pekerja sosial jika digabung dengan spiritualitas.

Dimensi berikutnya dari modal psikologis adalah self-efficacy. Dimensi ini ditemukan tidak memberikan pengaruh yang signifikan terhadap kesejahteraan karyawan di tempat kerja. Hasil penelitian ini memberikan bukti baru bahwa self-efficacy tidak selalu mampu meningkatkan kesejahteraan karyawan.

Hasil penelitian ini berbeda dengan temuan sebelumnya yang menyatakan bahwa self-efficacy yang tinggi akan diikuti dengan kesejahteraan yang tinggi pula. Sebut saja penelitian yang dilakukan oleh yang dilakukan oleh Malik (2013). Dalam penelitiannya tersebut, Malik (2013) menemukan bahwa self-efficacy memberikan pengaruh yang signifikan terhadap kesejahteraan karyawan bersama dengan ketahanan, sementara optimisme dan harapan tidak. Selain itu, terdapat juga penelitian yang dilakukan oleh Avey et al. (2010) yang menyatakan bahwa seluruh dimensi modal psikologis termasuk self-efficacy memberikan pengaruh positif terhadap kesejahteraan psikologis karyawan.

Beberapa penelitian lain yang juga menemukan bahwa selfefficacy tidak memberikan pengaruh signifikan terhadap kesejahteraan adalah penelitian yang dilakukan oleh Natovová dan Chýlová (2014). Dalam penelitiannya tersebut, Natovová dan Chýlová (2014) menemukan bahwa self-efficacy hanya mampu mereduksi stres kerja, namun tidak mampu meningkatkan kesejahteraan. Selain itu, Liu, Siu, dan Shi (2010), menemukan bahwa self-efficacy mampu memberikan pengaruh terhadap kesejahteraan karyawan setelah menjadi moderator dari kepemimpinan transformasional. Ketika self-efficacy berdiri sendiri, self-efficacy tidak mampu memberikan pengaruh terhadap kesejahteraan karyawan (Liu, Siu, 
\& Shi, 2010).

Dimensi berikutnya yang juga tidak memberikan pengaruh signifikan terhadap kesejahteraan karyawan adalah optimisme. Hasil penelitian ini berbeda dengan temuan dari penelitian yang dilakukan oleh Avey et al. (2010). Menurut Avey et al. (2010), seseorang yang optimis akan memiliki cara coping stres yang lebih efektif dibanding orang yang pesimis. Orang yang optimis memiliki cara pandang yang berbeda pada setiap situasi yang dihadapinya. Cara pandang yang positif ini lah yang akan membawa ia pada kesejahteraan. Selain itu, penelitian yang dilakukan oleh Cole, Daly dan Mak (2009) juga menemukan bahwa optimisme memiliki pengaruh yang signifikan terhadap kesejahteraan karyawan.

Meski ditemukan beberapa penelitian yang berbeda dengan hasil penelitian ini, ditemukan pula beberapa penelitian sejenis yang menemukan bahwa optimism tidak memberikan pengaruh signifikan terhadap kesejahteraan karyawan. Di antaranya adalah penelitian yang dilakukan oleh Malik (2013) serta Singh dan Mansi (2009). Bahkan dalam penelitian yang dilakukan oleh Singh dan Mansi (2009), optimisme tidak berkorelasi dengan kesejahteraan. Selain itu, dalam penelitian yang dilakukan oleh Karademas (2006), optimisme membutuhkan self-efficacy dan dukungan sosial untuk dapat memberikan pengaruh terhadap kesejahteraan.

Dimensi terakhir dari modal psikologis yang tidak memberikan pengaruh signifikan adalah ketahanan. Hasil penelitian ini tentu sangat unik, karena mayoritas penelitian sebelumnya menemukan bahwa ketahanan mampu meningkatkan kesejahteraan karena orang dengan tingkat ketahanan yang tinggi mampu bertahan dengan kondisi apa pun (Luthans et al., 2007). Dalam penelitian yang dilakukan oleh Avey et al. (2010) ditemukan bahwa dimensi ini memberikan pengaruh signifikan terhadap kesejahteraan psikologis karyawan. Kemudian, dalam penelitian yang dilakukan oleh Malik (2013) pun juga menemukan bahwa dimensi ini memberikan pengaruh signifikan terhadap kesejahteraan karyawan.

Temuan dalam penelitian yang penulis lakukan ini sejalan dengan temuan pada penelitian yang dilakukan oleh Harvey et al (2014) yang menyebutkan bahwa ketahanan akan mampu mempengaruhi kesejahteraan karyawan jika didukung dengan kondisi lingkungan dan sosial yang baik. Jika kedua hal tersebut tidak terpenuhi, maka ketahanan yang dimiliki karyawan hanya mampu membuat karyawan bertahan dengan tekanan yang dialaminya. Selain itu, menurut Friedli (2009), ketahanan hanya mampu membantu karyawan bangkit kembali dan memiliki cara mengatasi (coping) stres yang dialaminya, namun tidak mampu membawa kesejahteraan dan kepuasan terhadap pekerjaannya. 
Selanjutnya, hasil penelitian ini menunjukkan bahwa tiga dimensi dari persepsi kepemimpinan transformasional memberikan pengaruh yang signifikan terhadap workplace wellbeing. Dimensi-dimensi yang memberikan pengaruh signifikan tersebut adalah idealized influence, intellectual stimulation, individualized consideration.

Dimensi pertama, idealized influence. Dalam penelitian ini dimensi idealized influence signifkan memberikan pengaruh positif terhadap workplace wellbeing karyawan. Artinya, pemimpin yang memiliki karakteristikidealized influence dapatmeningkatkan kesejahteraan karyawan di tempat kerja. Temuan penelitian ini menguatkan hasil penelitian Nielsen, Yarker, Brenner, Randall dan Borg (2008) yang menemukan bahwa dimensi ini memiliki pengaruh terhadap wellbeing dan kepuasan kerja karyawan. Selain itu, penelitian Arnold et al. (2007) menemukan bahwa dimensi ini memberikan pengaruh positif terhadap kesejahteraan psikologis karyawan.

Menurut Sivanathan et al. (2004), idealized influence terjadi ketika para pemimpin memilih untuk melakukan apa yang etis daripada apa yang bijaksana, ketika dipandu oleh komitmen moral untuk pengikut, dan melampaui kepentingan pribadi untuk kepentingan organisasi. Pemimpin yang mampu memanifestasikan idealized influence mampu melepaskan tekanan organisasi untuk hasil keuangan jangka pendek, dan juga memfokuskan upaya pada kesehatan dan kesejahteraan karyawan. Sehingga, pemimpin dengan karakateristik ini dapat meningkatkan kesejahteraan karyawan.

Akan tetapi, hasil dalam penelitian ini berbeda dengan hasil penelitian yang dilakukan oleh Tafvelin, Armelius, dan Westerberg (2011). Dalam penelitiannya tersebut, dimensi idealized influence tidak memberikan pengaruh positif terhadap well being. Dimensi ini mampu memberikan pengaruh terhadap well being jika dimoderatori oleh dimensi lain dari kepemimpinan transformasional. Selain itu, menurut Sadeghi dan Pihie (2012) dimensi ini tidak akan memberikan pengaruh yang efektif jika tidak dibarengi dengan kemampuan pemimpin pada dimensi lain dari kepemimpinan transformasional.

Dimensi selanjutnya yang juga memberikan pengaruh positif adalah intellectual stimulation. Hasil penelitian ini menguatkan temuan dari Arnold et al. (2007) yang menemukan bahwa dimensi ini mampu meningkatkan kesejahteraan karyawan di tempat kerja. Selain penelitian dari Arnold et al. (2007), hasil penelitian ini juga sejalan dengan pendapat dari Sivanathan et al. (2004). Menurutnya, pemimpin yang memiliki sifat intelectual stimulation akan membantu karyawan untuk mempertanyakan asumsi sendiri, membingkai masalah, dan memberikan pendekatan dengan 
cara yang inovatif. Dengan demikian, karyawan akan menjadi lebih percaya diri dalam melindungi dan mengembangkan kesejahteraan sendiri. Pada saat yang sama, berpikir tentang tantangan dalam cara-cara baru memungkinkan karyawan untuk memahami situasi. Sehingga, pemimpin dengan karakteristik ini dapat membantu karyawan mencapai kesejahteraan di tempat kerja. Akan tetapi, menurut hasil penelitian yang dilakukan oleh Javeed dan Farooqi (2013), dimensi ini baru mempengaruhi kesejahteraan jika dimoderatori oleh kondisi kerja. Hal ini disebabkan bahwa meski pemimpin mampu memberikan pendekatan dengan cara yang inovatif, jika tidak didukung dengan kondisi kerja yang nyaman, tidak akan memberikan pengaruh terhadap kesejahteraan karyawan. Selain itu, menurut Sadeghi dan Pihie (2012) dimensi ini tidak akan memberikan pengaruh yang efektif jika tidak dibarengi dengan kemampuan pemimpin pada dimensi lain dari kepemimpinan transformasional.

Dimensi terakhir yang memberikan pengaruh positf terhadap workplace wellbeing adalah individualized influence. Temuan dalam penelitian ini pun sejalan dengan hasil dari penelitian yang dilakukan oleh Arnold et al. (2007) yang menemukan bahwa dimensi ini dapat meningkatkan kesejahteraan karyawan. Individualized consideration akan terjadi ketika para pemimpin memberikan perhatian khusus terhadap kebutuhan karyawan untuk pencapaian dan pengembangan diri. Para pemimpin dengan sifat ini akan memberikan empati, kasih sayang, dukungan, dan bimbingan yang akan mempengaruhi kesejahteraan karyawan. Meski demikian, hasil dalam penelitian ini berbeda dengan Kelloway, Turner, Barling, dan Loughlin (2012). Dalam penelitiannya ini dimensi ini harus dimoderatori oleh kepercayaan terhadap pemimpin baru dapat mempengaruhi kesejahteraan karyawan. Selain itu, menurut Sadeghi dan Pihie (2012) dimensi ini tidak akan memberikan pengaruh yang efektif jika tidak dibarengi dengan kemampuan pemimpin pada dimensi lain dari kepemimpinan transformasional.

Dalam penelitian ini, peneliti menyadari masih terdapat banyak kekurangan dalam penelitian ini. Sebagaimana telah disebutkan sebelumnya, bahwa penelitian terkait pengaruh modal psikologis terhadap workplace wellbeing karyawan masih sangat jarang ditemukan. Oleh karena itu, butuh kajian lebih mendalam terkait hubungan antar kedua variabel tersebut, terlebih lagi, dalam penelitian ini hanya ditemukan satu dimensi modal psikologis yang berpengaruh signifikan terhadap workplace wellbeing.

Selain itu, dalam penelitian ini peneliti menggunakan metode nonprobability sampling. Peneliti pun tidak diberi izin oleh pihak kementerian untuk bertemu dengan responden secara langsung. Sehingga, 
kemungkinan munculnya bias dalam penelitian ini sangat besar karena peneliti tidak mengetahui apakah sample yang dipilih sesuai dengan kriteria peneliti atau tidak. Selain itu, sample yang dipilih pun kemungkinan tidak representative menggambarkan kondisi populasi.

\section{Saran}

Pada penelitian ini, penulis membagi saran menjadi dua, yaitu saran metodologis dan saran praktis. Penulis memberikan saran secara metodologis sebagai bahan pertimbangan untuk perkembangan penelitian selanjutnya. Selain itu, penulis juga menguraikan saran secara praktis sebagai bahan kesimpulan dan masukan bagi pembaca sehingga dapat mengambil manfaat dari penelitian ini. Saran yang penulis berikan akan berdasarkan dengan temuan dalam penelitian yang telah penulis lakukan.

\section{Saran Metodologis}

Berdasarkan temuan dalam penelitian ini, ditemukan proporsi varian dari workplace wellbeing yang dijelaskan oleh persepsi kepemimpinan transformasional dan modal psikologis adalah sebesar 27,9\%, sedangkan $72,1 \%$ sisanya dipengaruhi oleh variabel lain di luar penelitian ini. Hal ini menunjukkan bahwa masih banyak variabel lain di luar penelitian ini yang dapat memberikan pengaruh terhadap workplace wellbeing. Selain itu, penelitian terkait yang menggunakan workplace wellbeing sebagai DV masih sangat jarang ditemukan, maka untuk penelitian selanjutnya dapat menggunakan faktor-faktor lain yang menarik yang dapat dijadikan variabel independent untuk melihat pengaruhnya terhadap workplace wellbeing, seperti, kepuasan kerja, komitmen organiasi, trust in organization, meaning full at work dan variabel individual difference lainnya. Populasi dan sampel dalam penelitian ini adalah para Pegawai Negeri Sipil Kementerian Pekerjaan Umum Direktorat Bina Pelaksanaan Wilayah II.

Hasil yang diperoleh pada penelitian ini terdapat empat variabel yang signifikan terhadap dependent variable, yaitu: harapan, idealized influence, intellectual stimulation, dan individualized consideration. Sedangkan empat variabel lainnya tidak signifikan terhadap dependent variable, yaitu: self-efficacy, optimisme, ketahanan, dan inspirational learning. Sehubungan dengan penjelasan diatas, penulis memberikan saran untuk penelitian selanjutnya, gunakan sampel yang berbeda. Sebaiknya sampel yang digunakan adalah subjek yang bekerja pada institusi/ perusahaan swasta (bukan PNS atau kampus), karena di perusahaan swasta perubahan sangat sering terjadi. sehingga diharapkan akan menghasilkan hasil yang bervariasi. Selain itu, di perusahaan swasta pun biasanya lebih mudah diberi 
izin untuk melakukan penelitian dibanding dengan instansi pemerintahan. Karena untuk melakukan penelitian di instansi pemerintahan harus melalui perizinan dan birokrasi yang cukup sulit.

\section{Saran Praktis}

Berdasarkan temuan dalam penelitian ini, ditemukan proporsi varian dari workplace wellbeing yang dijelaskan oleh persepsi kepemimpinan transformasional dan modal psikologis adalah sebesar 27,9\%, sedangkan $72,1 \%$ sisanya dipengaruhi oleh variabel lain di luar penelitian ini. Hal ini menunjukkan bahwa masih banyak variabel lain di luar penelitian ini yang dapat memberikan pengaruh terhadap workplace wellbeing. Selain itu, penelitian terkait yang menggunakan workplace wellbeing sebagai DV masih sangat jarang ditemukan, maka untuk penelitian selanjutnya dapat menggunakan faktor-faktor lain yang menarik yang dapat dijadikan variabel independent untuk melihat pengaruhnya terhadap workplace wellbeing, seperti, kepuasan kerja, komitmen organiasi, trust in organization, meaning full at work dan variabel individual difference lainnya. Populasi dan sampel dalam penelitian ini adalah para Pegawai Negeri Sipil Kementerian Pekerjaan Umum Direktorat Bina Pelaksanaan Wilayah II. Hasil yang diperoleh pada penelitian ini terdapat empat variabel yang signifikan terhadap dependent variable, yaitu: harapan, idealized influence, intellectual stimulation, dan individualized consideration. Sedangkan empat variabel lainnya tidak signifikan terhadap dependent variable, yaitu: self-efficacy, optimisme, ketahanan, dan inspirational learning. Sehubungan dengan penjelasan diatas, penulis memberikan saran untuk penelitian selanjutnya, gunakan sampel yang berbeda. Sebaiknya sampel yang digunakan adalah subjek yang bekerja pada institusi/ perusahaan swasta (bukan PNS atau kampus), karena di perusahaan swasta perubahan sangat sering terjadi. sehingga diharapkan akan menghasilkan hasil yang bervariasi. Selain itu, di perusahaan swasta pun biasanya lebih mudah diberi izin untuk melakukan penelitian dibanding dengan instansi pemerintahan. Karena untuk melakukan penelitian di instansi pemerintahan harus melalui perizinan dan birokrasi yang cukup sulit.

\section{Referensi}

Avey, J. B., Luthans, F., \& Jensen, S. M. (2009). Psychological capital: A positive resource for combating employee stress and turnover. Human Resource Management, 48, 677-693.doi.10.1002/hrm.20294 
Anwarsyah, W.I., Salendu, A., \& Radikun, T. B. S. (2012). Hubungan antara job demands dengan workplace well-being pada pekerja shift. Jurnal Psikologi Pitutur, 1(1), 32-44.

Arnold KA, Turner N, Barling J, Kelloway EK \& McKee M (2007) Transformational leadership and psychological well-being: The mediating role of meaningful work. Journal of Occupational Health Psychology, 12, 193-203.doi:10.1037/1076-8998.12.3.193

Avey, J.B., Luthans, F., Smith, R.M., \& Palmer, N.F. (2010). Impact of positive psychological capital on employee well-being over time. Journal of Occupational Health Psychology, 15(1), 17-28.doi:10.1037/a0016998

Bandura, A. (1977). Self-efficacy: Toward a unifying theory of behavioral change. Psychological Review, 84(2), 191-215.

Bass, B.M. (1990). From transactional to transformational leadership: Learning to share the vision. Organizational Dynamics, 18 (3), 19-31.

Beas, M. I. \& Salanova, M. (2004). Self-efficacy beliefs, computer training and psychological well-being among information and communication technology workers. Computers in Human Behavior, 22, 1043-1058.

Beşiktaş, M. Y. \& Orta, L. (2012). Measuring Leadership conditions of the coaches considering some factors. International Journal of Humanities and Social Science, 2(19), 210-213.

Bono, J.E., \& Ilies, R. (2006). Charisma, positive emotions and mood contagion. The Leadership Quarterly, 17, 317-334.doi:10.1016/J.lcaqua.2006.04.009

Bushra, F., Usman, A., Naveed, A. (2011).Effect of transformational leadership on employees' job satisfaction and organizational commitment in banking sector of Lahore (Pakistan). International Journal of Business and Social Science, 2(18), 261-267.

Carver, C. S., Scheier, M. F., \& Segerstrom, S. C (2010). Optimism. Clinical Psychology Review, 30, 879-889.doi.10.1016/J.cpr.2010.01.006

Danna, K. \& Griffin, R.W. (1999). Health and well-being in the workplace: A review and synthesis of the literature. Journal of Management, 25(3), 357384.

doi:10.1177/1014920639902500305

Eddington, N. \& Shuman, R. (2005). Subjective well being (happiness). Continuing psychology education: 6 continuing education hours. Diunduh pada 7 Februari 2015 dari http://www.texcpe.com/cpe/PDF/ca-happiness. pdf.

Ghadi, M. Y., Fernando, M., \& Caputi, P. (2013). Transformational leadership and work engagement: The mediating effect of meaning in work. Leadership \& Organization Development Journal, 34(6), 532-550. 
Javeed, T, \& Farooqi, AY. (2013). Impact of transformational leadership style on employees' satisfaction and well-being with working conditions as mediator. International Journal of Multidisciplinary Sciences and Engineering, 4 (7), $1-8$.

Kelloway, E.K., Turner, N., Barling, J., \& Loughlin, C. (2012). Transformational leadership and employee psychological well-being: The mediating role of employee trust in leadership. Work \& Stress: An International Journal of Work, Health \& Organisations, 26 (1), 39-55.

Kuster, F., Orth, U., \& Meier L(2013). High Self-Esteem Prospectively Predicts Better Work Conditions and Outcomes. Social Psychological and Personality Science, 4(6), 668-675.

Luthans, F., Luthans, K. W., \& Luthans, B. C. (2004). Positive psychological capital: Beyond human and social capital. Business Horizons, 47(1), 45-50.

Luthans, F., Youssef, C. M., \& Avolio, B. J. (2007). Psychological capital: Developing the human competitive edge. New York: Oxford University Press.

Malik, A. (2013). Efficacy, hope, optimism and resilience at workplace - positive organizational behavior. International Journal of Scientific and Research Publications, 3(10), 1-4.

Mortazavi, S., Yazdi, V. S. S., \& Amini, A. (2012). The role of the psychological capital on quality of work life and organization performance. Interdisciplinary Journal of Contemporary Research in Business, 4(2), 206-217.

Nielsen K, Yarker J, Brenner SO \& Randall R (2008). The importance of transformational leadership style for the well-being of employees working with older people. Journal of Advanced Nursing, 63, 165-175.doi:10.1111/ j.1365-2648.2008.04701.x.

Page, Kathryn. (2005). Subjective wellbeing in the workplace. Thesis. School of Psychology Faculty of Health and Behavioural Sciences Deakin University

Riaz, A. \& M.H. Haider. (2010). Role of transformational and transactional leadership with job satisfaction and career satisfaction. Business and Economics Horizons (BEH), 1(1), 56-64.

Ryff, C. D., \& Keyes, C. L. M. (1995). The structure of psychological well-being revisited. Journal of Personality and Social Psychology, 69, 719-727.

Schimmack, U., \& Diener, E. (2003). Predictive validity of explicit and implicit self-esteem for subjective well-being. Journal of Research in Personality, 37, 100-106.

Sivanathan, N., Arnold, K., Turner, N., \& Barling, J. (2004). Transformational leadership and well-being. In A. Linley \& S. Joseph (Eds.). Positive psychology in practice. (pp. 241-255). Hoboken, NJ: Wiley. 
Stajkovic, A. D., \& Luthans, F. (1988). Self-efficacy and work-related performance: A meta-analysis. Psychological Bulletin, 124(2), 240-261. doi:10.1037/0021-9010.92.1.107

Tafvelin, S., Armelius, K., \& Westerberg, K. (2011). Toward understanding the direct and indirect effects of transformational leadership on well-being: A longitudinal study. Journal of Leadership and Organizational Studies, 18 (4), 480-492.doi:10.1177/1548051811418342

Umar, J. (2010). Materi kuliah statitika 3

Van Dierendonck, D., Haynes, C., Borrill, C., \& Stride, C. (2004). Leadership behavior and subordinate well-being. Journal of Occupational Health Psychology, 9, 165-175.doi:10.1037/1076-8998.9.2.165

Youssef, C. M., \& Luthans, F. (2007). Positive organizational behavior in the workplace: The impact of hope, optimism, and resilience. Journal of Management, 33(5), 774-800.doi:10.1177/0149206307305562

Yukl, G. (1999). An evaluative essay on current conceptions of effective leadership. European Journal Of Work And Organizational Psychology, 8 (1), 33-4.

Zulkosky, K. (2009). self-efficacy: A concept analysis. Journal Compilation, 44 (2), 93-102. 